\title{
Fe304@polyaniline yolk-shell micro/nanospheres as bifunctional materials for lithium storage and electromagnetic wave absorption
}

Wang, Xiaoliang; Zhang, Minwei; Zhao, Jianming; Huang, Guoyong; Sun, Hongyu

Published in:

Applied Surface Science

Link to article, DOI:

10.1016/j.apsusc.2017.09.118

Publication date:

2017

Document Version

Peer reviewed version

Link back to DTU Orbit

Citation (APA):

Wang, X., Zhang, M., Zhao, J., Huang, G., \& Sun, H. (2017).Fe_O @polyaniline yolk-shell micro/nanospheres as bifunctional materials for lithium storage and electromagnetic wave absorption. Applied Surface Science, 427(Part B), 1054-1063. https://doi.org/10.1016/j.apsusc.2017.09.118

\section{General rights}

Copyright and moral rights for the publications made accessible in the public portal are retained by the authors and/or other copyright owners and it is a condition of accessing publications that users recognise and abide by the legal requirements associated with these rights.

- Users may download and print one copy of any publication from the public portal for the purpose of private study or research.

- You may not further distribute the material or use it for any profit-making activity or commercial gain

- You may freely distribute the URL identifying the publication in the public portal 


\section{$\mathrm{Fe}_{3} \mathrm{O}_{4} @$ polyaniline yolk-shell micro/nanospheres as bifunctional materials for lithium storage and electromagnetic wave absorption}

Xiaoliang Wang ${ }^{a}$, Minwei Zhang ${ }^{b}$, Jianming Zhao ${ }^{b}$, Guoyong Huang ${ }^{c,}{ }^{*}$, Hongyu Sun ${ }^{d, *}$

${ }^{a}$ College of Science, Hebei University of Science and Technology, Shijiazhuang 050018, China

${ }^{\mathrm{b}}$ Department of Chemistry, Technical University of Denmark, Kongens Lyngby 2800, Denmark

c School of Metallurgy and Environment, Central South University, Changsha 410083, China

d Department of Micro- and Nanotechnology, Technical University of Denmark, Kongens Lyngby 2800, Denmark

*Corresponding authors. E-mail address: huanggy@csu.edu.cn (G. Huang), hsun@ nanotech.dtu.dk (H. Sun)

\section{Graphical Abstract}

$\mathrm{Fe}_{3} \mathrm{O}_{4} @$ polyaniline yolk-shell micro/nanospheres synthesized by a facile silica-assisted solution phase method show excellent bifunctional properties when used as lithium ion battery anodes and electromagnetic wave absorbers.

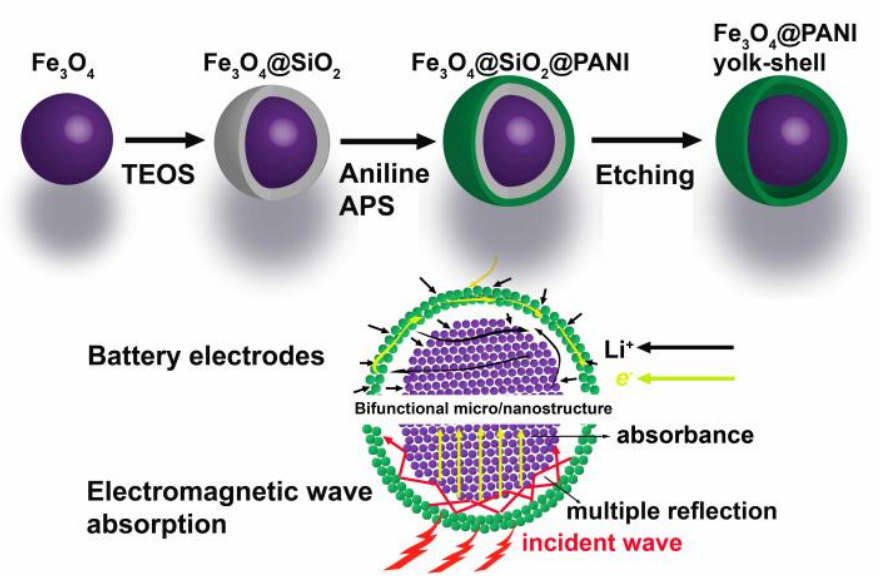




\section{Highlights}

- $\quad \mathrm{Fe}_{3} \mathrm{O}_{4} @$ polyaniline yolk-shell micro/nanospheres were synthesized.

- The sample exhibits excellent lithium storage properties.

- The sample possesses good electromagnetic wave absorption properties.

- The excellent bifunctional properties are associated with the unique micro/nanostructures.

\section{ABSTRACT}

Unique $\mathrm{Fe}_{3} \mathrm{O}_{4} /$ polyaniline (PANI) composite with yolk-shell micro/nanostructure (FPys) has been successfully synthesized by a facile silica-assisted in-situ polymerization and subsequent etching strategy. The structural and compositional studies of the FPys composites are performed by employing X-ray diffraction (XRD), and X-ray photoelectron spectroscopy (XPS). The yolk-shell morphology of the products is confirmed by scanning electron microscopy (SEM) and transmission electron microscopy (TEM) observations. When evaluated as anode material for lithium-ion batteries, the as-prepared FPys electrodes deliver superior capacity, better cycling stability and rate capability than those of bare $\mathrm{Fe}_{3} \mathrm{O}_{4}$ micro/nanospheres and $\mathrm{Fe}_{3} \mathrm{O}_{4} / \mathrm{PANI}$ core-shell (FPcs) electrodes. Moreover, FPys also exhibits excellent electromagnetic wave absorption performance when comparing to the synthesized $\mathrm{Fe}_{3} \mathrm{O}_{4}$-based electromagnetic wave absorbers, in which strong reflection loss and extensive response bandwidth can be achieved simultaneously. The excellent bifunctional properties of FPys material are associated with the specially designed hierarchical micro/nanostructures. The current strategy that application directed structural design can be applied to the synthesis of other multifunctional materials.

Keywords: $\mathrm{Fe}_{3} \mathrm{O}_{4}$; polyaniline; yolk-shell; anodes; lithium storage; electromagnetic wave 
absorption

\section{Introduction}

Energy and environment are important factors those affect the sustainable development of the society [1]. Typical examples include the expanding of various electronic and communication devices in the past decades. Those techniques definitely facilitate and enrich the daily life, however, energy usage and environment protection related issues raise at the same time. Firstly, the pace of R\&D for energy storage (such as lithium ion batteries, LIBs) and mobile devices should be coordinated [2]. Secondly, the environment pollution induced by the excessive electromagnetic radiation must be solved $[3,4]$. In this regard, multifunctional material that simultaneously possesses excellent lithium storage and electromagnetic wave absorption abilities would be highly needed. Design and synthesis of those materials with suitable size, morphology, and composition are essential to achieve the required multifunction since the overall device performance is dependent on those structural parameters [5-7].

LIBs with long cycle life, high capacity, and good rate capability attract considerable responsiveness. The specific energy of the commercialized LIBs is insufficient due to the low capacity of electrode materials $[8,9]$. Therefore, developing advanced electrodes is one of the key elements that relates to the battery performance improvement. In recent years, great efforts have been paid to design high performance anodes, including carbon materials, alloys, transition-metal compounds, and their composites [10-14]. Among them, magnetite $\left(\mathrm{Fe}_{3} \mathrm{O}_{4}\right)$ has been extensively studied for anode materials due to the obvious advantages including environmental benignity, natural abundance, low cost, and high theoretical capacity $\left(926 \mathrm{~mA} \mathrm{~h} \mathrm{~g}^{-1}\right.$, higher than the 
commercial used graphite with a capacity of $372 \mathrm{~mA} \mathrm{~h} \mathrm{~g}^{-1}$ ) $[15,16]$. The storage of lithium in $\mathrm{Fe}_{3} \mathrm{O}_{4}$ anodes is through electrochemical conversion reaction mechanism $\left(\mathrm{Fe}_{3} \mathrm{O}_{4}+8 \mathrm{Li}^{+}+8 \mathrm{e}^{-} \leftrightarrow\right.$ $\left.3 \mathrm{Fe}+4 \mathrm{Li}_{2} \mathrm{O}\right)$ [17]. This reaction, however, is not efficient and reversible in bulk $\mathrm{Fe}_{3} \mathrm{O}_{4}$ electrodes. In addition, the $\mathrm{Fe}_{3} \mathrm{O}_{4}$ bulk anode undergoes unavoidable large volume expansion and severe particle aggregation during charging and discharging process, which results in the deterioration of reversible capacity and poor cycling stability. To improve the battery durability, reversible capacity, as well as rate capability of $\mathrm{Fe}_{3} \mathrm{O}_{4}$ anodes, a wide range of nanostructures with optimized morphology, composition, and assembly have been designed and synthesized [18-20]. Those nanostructures not only offer extra active sites for lithium storage, but also facilitate the rapid and efficient transportation for mass and ion/electron, and accommodate the localized strain generation during continuous cycling. Combining the anodes with conducting mediums, such as carbon nanotube/fiber, graphene, or conducting polymers, is another effective method to improve the battery performance [21-37]. Those nanocomposites can prevent the electrode cracking and improve the electrode kinetics through conductivity enhancement. Polyaniline (PANI) represents one of the most attractive conducting polymers thanks to its excellent conductivity, chemical/physical stability, and commercial viability, and it is also widely used as a efficient conducting medium to prepare metal oxides and PANI hybrids with improved lithium storage properties $[38,39]$. For example, $\mathrm{Fe}_{2} \mathrm{O}_{3}$ nanorods and PANI composite anodes show a reversible capacity of $778 \mathrm{~mA} \mathrm{~h} \mathrm{~g}^{-1}$ at a current of $1.0 \mathrm{~A} \mathrm{~g}^{-1}$ after 100 cycles [40]. $\mathrm{Fe}_{2} \mathrm{O}_{3}$ nanourchins modified with PANI layers possess good electrochemical properties after long term cycling [41]. Although different kinds of $\mathrm{Fe}_{3} \mathrm{O}_{4}$ and PANI composites have been synthesized by employing a wide range of polymerization routes or self-assembly methods [42-46], less attention has been 
paid to study the lithium storage properties of $\mathrm{Fe}_{3} \mathrm{O}_{4} / \mathrm{PANI}$ composite anodes.

With regard to the electromagnetic wave absorption applications, materials should possess the properties of strong magnetic and dielectric loss, as well as suitable impedance matching. $\mathrm{Fe}_{3} \mathrm{O}_{4}$ nanostructures are considered as promising electromagnetic wave absorber due to the unique magnetic feature and strong spin polarization, which are favorable for the magnetic loss [47]. However, the intrinsic low complex permittivity in $\mathrm{Fe}_{3} \mathrm{O}_{4}$ materials leads to poor dielectric loss and thus microwave absorption properties. To boost the electromagnetic wave absorption ability of $\mathrm{Fe}_{3} \mathrm{O}_{4}$ materials, strategies based on integrating $\mathrm{Fe}_{3} \mathrm{O}_{4}$ nanostructures with different components (such as carbon materials and conducting polymers) and microstructure design on the nanoscale have been proposed [48]. Typically, $\mathrm{Fe}_{3} \mathrm{O}_{4} / \mathrm{PANI}$ composites were constructed to adjust and improve the dielectric loss of $\mathrm{Fe}_{3} \mathrm{O}_{4}$ structures [49]. $\mathrm{Fe}_{3} \mathrm{O}_{4}$ nanowires, nanorings, and other hierarchical nanostructures were synthesized to yield multiple reflection and scattering of the incident waves inside the nanoarchitectures, which are helpful to attenuating the electromagnetic waves $[50,51]$. Combining the composting and microstructure control together will be a possible route to further enhance the electromagnetic wave absorption properties of $\mathrm{Fe}_{3} \mathrm{O}_{4}$ materials.

Considering the similar microstructure requirements for the applications in LIB anodes and electromagnetic wave absorption, in this work, we design and synthesize bifunctional $\mathrm{Fe}_{3} \mathrm{O}_{4} @$ polyaniline yolk-shell (FPys) micro/nanospheres via a facile silica-assisted solution phase route. Microstructure characterizations showed that the yolks $\left(\mathrm{Fe}_{3} \mathrm{O}_{4}\right.$ micro/nanospheres) were assembled by nanoparticles with porous structures, and void spaces existed between the inner $\mathrm{Fe}_{3} \mathrm{O}_{4}$ and outer PANI parts, indicating the formation of typical yolk-shell structures. Such unique hierarchical nanostructures enhance the physical and chemical properties. For example, the 
micro/nanoarchitecture is favored for preventing the aggregation of the subunits during the usage, the porous yolks and void spaces can ensure short transport length for lithium ions and electrons, and also provide extra sites for ion storage, and the PANI layer can effectively enhance the conductivity. Moreover, this structural design based on FPys micro/nanospheres can not only improve the dielectric loss, but also reinforce the reflection loss from the incident electromagnetic waves (Scheme 1). The resultant FPys micro/nanospheres thus show excellent bifunctional properties in terms of lithium storage and electromagnetic wave absorption, which are superior to those of $\mathrm{Fe}_{3} \mathrm{O}_{4} @$ polyaniline core-shell (FPcs) and bare $\mathrm{Fe}_{3} \mathrm{O}_{4}$ micro/nanospheres. The current strategy that application directed structural design can also be applied to the synthesis of other high-performance-multifunction materials.

\section{Experimental}

\subsection{Materials synthesis}

Synthesis of $\mathrm{Fe}_{3} \mathrm{O}_{4}$ micro/nanospheres: The $\mathrm{Fe}_{3} \mathrm{O}_{4}$ microspheres were synthesized by a facile hydrothermal method. In a typical synthesis, an ethylene glycol solution $(40 \mathrm{~mL})$ containing iron(III) chloride hexahydrate $\left(\mathrm{FeCl}_{3} \cdot 6 \mathrm{H}_{2} \mathrm{O}, 1.35 \mathrm{~g}\right)$ and sodium acetate anhydrous $\left(\mathrm{CH}_{3} \mathrm{COONa}\right.$, $3.3 \mathrm{~g}$ ) was added into a $50 \mathrm{~mL}$ Teflon-lined stainless-steel autoclave. The homogeneous mixture was stirred for $30 \mathrm{~min}$ and then maintained at $200{ }^{\circ} \mathrm{C}$ for $10 \mathrm{~h}$. The obtained precipitates were washed with ethanol and deionized water several times and then dried at $60^{\circ} \mathrm{C}$.

Synthesis of FPys micro/nanospheres: $\mathrm{Fe}_{3} \mathrm{O}_{4}$ microspheres were coated with silica shells those synthesized by a modified Stöber method $[52,53]$. The products were dispersed in ethanol (300 $\mathrm{mL}$ ) by sonication with the subsequent addition of polyvinylpyrrolidone (PVP, $0.1 \mathrm{~g}$ ). Aniline 
solution $(0.5 \mathrm{~mL})$ was then injected into the above mixture. After stirring for $5 \mathrm{~min}, \mathrm{HCl}(25.0 \mathrm{~mL}$, $1.21 \mathrm{~mol} / \mathrm{L}$ ) containing ammonium peroxydisulfate (APS, $1.55 \mathrm{~g}$ ) was added. To achieve a full polymerization, the suspension was kept on stirring at $\sim 0{ }^{\circ} \mathrm{C}$ for $24 \mathrm{~h}$. The $\mathrm{SiO}_{2}$ spacer shell was removed with $\mathrm{NaOH}$ solution to yield the final FPys micro/nanospheres.

\subsection{Structural characterization}

The morphology, composition as well as crystal structure of the products were examined by field-emission scanning electron microscope (FESEM; Hitachi, S5500, $5 \mathrm{kV}$; Zeiss, MERLIN, 5 $\mathrm{kV}$ ), transmission electron microscope equipped with an energy dispersive X-ray (EDX) system (TEM; FEI, Tecnai T20 G², $200 \mathrm{kV}$; JEOL, JEM-2100, $200 \mathrm{kV}$ ), X-ray photoelectron spectroscopy (XPS, Escalab 250, Al Ka) and thermal gravimetric analysis (TGA; Netzsch-STA 449C). Phase structure and surface functional groups were determined by a Bruker Model D8 Advance powder X-ray diffractometer (XRD) with $\mathrm{Cu} K_{\alpha}$ irradiation $(\lambda=1.5418 \AA)$ and a Fourier

transform infrared spectroscopy (FTIR; Spotlight 3000). The Bruauer-Emmett-Teller (BET) surface area was measured by nitrogen adsorption-desorption isotherm at $77 \mathrm{~K}$ (Micromeritics ASAP 2010 system). The nitrogen adsorption volume at the relative pressure $\left(P / P_{0}\right)$ of 0.994 was used to analyze the pore volume and average pore size.

\subsection{Electrochemical measurements}

The working electrodes for electrochemical performance measurements were constructed by mixing the active materials, conductive carbon black and carboxymethyl cellulose (weight ratio 80:10:10) in the Milli-Q water. The yielded slurry was spread onto a copper foil with typical active material loading of 3.2-4.5 mg cm . $^{-2}$ The electrode was dried at $120^{\circ} \mathrm{C}$ for $5 \mathrm{~h}$ before cut into disks with diameter of $12 \mathrm{~mm}$ and dried again in vacuum at $100{ }^{\circ} \mathrm{C}$ for $24 \mathrm{~h}$. CR 2032 coin-type half 
cells were assembled inside an Ar-filled glove box by using a lithium metal foil as the counter electrode and the reference electrode and microporous polypropylene as the separator. The electrolyte was made by dissolving $1 \mathrm{M} \mathrm{LiPF}_{6}$ in a mixture of ethylene carbonate (EC), propylene carbonate $(\mathrm{PC})$, and diethyl carbonate $(\mathrm{DEC})$ (volume ratio $\mathrm{EC} / \mathrm{PC} / \mathrm{DEC}=3: 1: 1$ ). The electrochemical tests were performed on a LAND battery test unit at room temperature. Galvanostatic charge and discharge of the assembled cells were evaluated at a current density of $100 \mathrm{~mA} \mathrm{~g}^{-1}$ between voltage limits of 0.05 and $3 \mathrm{~V}\left(\mathrm{vs} . \mathrm{Li}^{+} / \mathrm{Li}\right)$ for 50 cycles. For the high rate tests, the discharge current gradually increased from $50 \mathrm{~mA} \mathrm{~g}^{-1}$ to 100,500 and $1000 \mathrm{~mA} \mathrm{~g}^{-1}$, and then decreased to $50 \mathrm{~mA} \mathrm{~g}^{-1}$. The cyclic voltammogram $(\mathrm{CV})$ was recorded between 0.05 and $3 \mathrm{~V}$ (vs. $\mathrm{Li}^{+} / \mathrm{Li}$ ) at a scan rate of $0.5 \mathrm{mV} \mathrm{s}^{-1}$ by using a CHI 660D electrochemical workstation (Chenhua Instrument, Shanghai). Electrochemical impedance spectroscopy (EIS, IM6, Zahner) was carried out at open circuit potential by applying an AC voltage of $5 \mathrm{mV}$ over a frequency range of 100 kHz to $0.01 \mathrm{~Hz}$.

\subsection{Electromagnetic wave absorption measurements}

The electromagnetic parameters were measured by an Agilent N5244A vector network analyzer (VNA, USA) with coaxial method. The samples were dispersed in paraffin wax with a mass ratio of $1: 1$, and then pressed into toroidal shap with outer diameters of $7 \mathrm{~mm}$ and inner diameters of $3 \mathrm{~mm}$. The relative complex permittivity $\left(\varepsilon_{r}, \varepsilon_{r}=\varepsilon^{\prime}-j \varepsilon^{\prime \prime}, \varepsilon^{\prime}\right.$ and $\varepsilon^{\prime \prime}$ are the real and imaginary parts) and permeability $\left(\mu_{r}, \mu_{r}=\mu^{\prime}-j \mu^{\prime \prime}, \mu^{\prime}\right.$ and $\mu^{\prime \prime}$ are the real and imaginary parts) were determined from S-parameters taking advantage of the simulation program of the Reflection/Transmission Nicolson-Ross model [54]. The reflection loss was calculated by the following equation [42-47]: $\mathrm{RL}(\mathrm{dB})=20 \log _{10}\left|\left(Z_{\mathrm{in}}-1\right)\left(Z_{\mathrm{in}}+1\right)\right|$, where $Z_{\text {in }}$ is the input impedance, 
$\left.Z_{\text {in }}=\sqrt{\mu_{\mathrm{r}} / \varepsilon_{\mathrm{r}}} \tanh \mid j(2 \pi f D / c) \sqrt{\mu_{\mathrm{r}} \varepsilon_{\mathrm{r}}}\right\rfloor$, where $f, D$, and $c$ represent the electromagnetic wave frequency in free space, coating thickness of the absorbent, and velocity of light, respectively.

\section{Results and discussion}

\subsection{Morphology and microstructure of the samples}

Fig. 1 displays XRD pattern of the FPys micro/nanospheres. The pattern of $\mathrm{Fe}_{3} \mathrm{O}_{4}$ micro/nanospheres is also shown for comparison. The diffraction peaks of the samples match well with the standard pattern of magnetite $\mathrm{Fe}_{3} \mathrm{O}_{4}$ with inverse spinel structure (JCPDS card No. 19-0629, a= $8.396 \AA$ ). The samples are high purity since no other diffraction peaks from possible impurities are observed. The relatively high peak intensities and broad peak widths imply that the samples are highly crystalline with small size. The crystallite sizes $(d)$ of $\mathrm{Fe}_{3} \mathrm{O}_{4}$ phase in the samples can be estimated from the physical breadth of diffraction peaks as expressed by the Scherrer formula: $d=0.89 \lambda / \beta \cos \theta$, where $\lambda$ is the $\mathrm{X}$-ray wavelength, $\beta$ is the full width at half maximum of the diffraction peak, and $\theta$ is the diffraction angle [55]. The average crystallite sizes of $\mathrm{Fe}_{3} \mathrm{O}_{4}$ phase in $\mathrm{FPys}$ and $\mathrm{Fe}_{3} \mathrm{O}_{4}$ micro/nanospheres are calculated to be $\sim 12.5$ and $13.7 \mathrm{~nm}$ by using (311) diffraction peak. For FPys sample, no distinct diffraction peaks corresponding to PANI are detected which may due to its amorphous nature.

The presence of PANI in FPys sample is confirmed by FTIR technique, which is able to identify functional groups in organic molecules based on the vibration modes at different infrared wave numbers. Typical FTIR spectra for FPys and PANI show similar character in the low wavenumber region (Fig. S1). In the spectrum for pure PANI sample, the peaks at $\sim 1561$ and $1483 \mathrm{~cm}^{-1}$ are accounting for the $\mathrm{C}=\mathrm{C}$ stretching vibration of the quinoid and benzene rings, showing the 
presence of PANI with a conducting state (emeraldine salt) [56]. The vibration modes at $\sim 1298$ and $1111 \mathrm{~cm}^{-1}$ are due to the $\mathrm{C}-\mathrm{N}$ stretching vibration of the secondary aromatic amine and $\mathrm{C}=\mathrm{N}$ stretching vibration $(-\mathrm{N}=$ quinoid=N-) in the aromatic ring [57]. The modes located between 850 and $500 \mathrm{~cm}^{-1}$ are corresponding to the $\mathrm{C}-\mathrm{H}$ vibration of benzene rings [58]. The FTIR results for FPys sample show combined characteristic of both $\mathrm{Fe}_{3} \mathrm{O}_{4}$ and PANI, demonstrating the existence of PANI in the FPys composites [59]. The content of PANI is further determined by TGA and derivative thermogravimetric (DTG) studies as shown in Fig. S2. The pristine PANI shows a gradual decrease in mass from room temperature to $250^{\circ} \mathrm{C}$ due to the desorption of residual water or other possible smaller oligomeric units. Starting from $\sim 300{ }^{\circ} \mathrm{C}$, the mass decreasing is associated with the loss of acid dopant in PANI. The PANI polymer is completely combusted above $600{ }^{\circ} \mathrm{C}$. The thermal gravimetric response for FPys micro/nanospheres show similar trends. A small weight loss before $100{ }^{\circ} \mathrm{C}$ is attributed to the evaporation of gaseous content, moisture and trace ethanol. The degradation of PANI can be observed at $\sim 250{ }^{\circ} \mathrm{C}$, which stops at $\sim 450{ }^{\circ} \mathrm{C}$. Both the temperatures are lower than those for the pristine PANI, indicating the polymer is more thermal active when composting with $\mathrm{Fe}_{3} \mathrm{O}_{4}$ micro/nanospheres. The total mass loss of $22.5 \%$ taking place in the temperature range of $250-450{ }^{\circ} \mathrm{C}$ can be ascribed to the combustion of PANI and oxidation of $\mathrm{Fe}_{3} \mathrm{O}_{4}$ to $\mathrm{Fe}_{2} \mathrm{O}_{3}$ in the air atmosphere. Based on the mass change and the oxidation reaction of $\mathrm{Fe}_{3} \mathrm{O}_{4}\left(4 \mathrm{Fe}_{3} \mathrm{O}_{4}+\mathrm{O}_{2}=6 \mathrm{Fe}_{2} \mathrm{O}_{3}\right)[60,61]$, the contents of PANI and $\mathrm{Fe}_{3} \mathrm{O}_{4}$ in the FPys micro/nanospheres are estimated to be $\sim 25.3 \mathrm{wt} \%$ and $74.7 \mathrm{wt} \%$, respectively.

Typical FESEM image (Fig. 2a) of the FPys sample show that high density spheres with submicrometer (200-600 nm) diameter and rough surface are dispersed over the substrate. Higher magnification FESEM image shown in Fig. $2 b$ displays an individual micro/nanosphere with 
broken shell. The void space between the $\mathrm{Fe}_{3} \mathrm{O}_{4}$ and PANI part indicated by white arrows unambiguously shows the yolk-shell structural nature of the micro/nanospheres. TEM images (Fig. 2c-e) show that the inner $\mathrm{Fe}_{3} \mathrm{O}_{4}$ spheres possess a diameter ranging from 200 to $500 \mathrm{~nm}$, while the PANI shells with lower contrast are coated on to the $\mathrm{Fe}_{3} \mathrm{O}_{4}$ with void spaces (see the white arrows). The selected area electron diffraction (SAED) pattern (Fig. 2f) indicates the FPys sample is polycrystalline structure, and the $\mathrm{Fe}_{3} \mathrm{O}_{4}$ yolks are assembled by primary particle with size of $\sim 10$ $\mathrm{nm}$ and there exists porous gap between each particle (Fig. 2e). HRTEM images (Fig. 2g-i) exhibit clear lattice fringes with spacing values of 4.83-4.87, 2.51-2.53, 2.11, and $2.91 \AA$, which are in good agreement with the (111), (311), (400), and (220) crystalline planes of cubic-phase $\mathrm{Fe}_{3} \mathrm{O}_{4}$. The amorphous PANI shells without lattice fringe are also clearly observed. The EDX result (Fig. 2c inset) shows that the FPys sample is composed of $\mathrm{Fe}, \mathrm{O}, \mathrm{N}$ (the $\mathrm{Cu}$ signal comes from the supported $\mathrm{Cu}$ grip), and the atomic ratio is $\sim 3: 4$ for element $\mathrm{Fe}$ to element $\mathrm{O}$, also confirming the formation of FPys composites. Reference samples were also synthesized for structural studies as shown in Fig. S3-7. The results indicate that the size of $\mathrm{Fe}_{3} \mathrm{O}_{4}$ micro/nanospheres in the different samples is similar, while there is no PANI coatings in pure $\mathrm{Fe}_{3} \mathrm{O}_{4}$ micro/nanospheres, and a close contact is formed between $\mathrm{Fe}_{3} \mathrm{O}_{4}$ and PANI in the FPcs micro/nanospheres. Elemental mapping results (Fig. S8) of the three samples further demonstrate the spatial distribution of $\mathrm{Fe}, \mathrm{O}$, and $\mathrm{N}$ elements, which agree well with the TEM results.

The chemical composition and surface oxidation state of FPys and $\mathrm{Fe}_{3} \mathrm{O}_{4}$ micro/nanospheres were analysized by XPS in the region of 0-1350 eV. Fig. 3a shows the survey XPS spectrum of FPys sample that contains $\mathrm{Fe}, \mathrm{O}, \mathrm{N}$, and $\mathrm{C}$ elements, which are in accordance with the EDX and elemental mapping results. 
The high-resolution XPS spectrum of Fe $2 p$ (Fig. 3b) shows two main binding energy peaks cantered at $\sim 710.7$ and $724.7 \mathrm{eV}$, which are corresponding to the electronic states of $\mathrm{Fe} 2 \mathrm{p} 3 / 2$ and Fe 2p1/2, respectively. The two peaks can be fitted with two pair spin-orbit doublets those are the characteristic peaks of $\mathrm{Fe}^{2+}$ and $\mathrm{Fe}^{3+}[62,63]$. The ratio of $\mathrm{Fe}^{3+} / \mathrm{Fe}^{2+}$ calculated from the peak area is 2.1:1, which is close to the theoretical value of $2: 1$ in $\mathrm{Fe}_{3} \mathrm{O}_{4}$. It should be noted that the absent of satellite peak situated at $\sim 719-720 \mathrm{eV}$ excludes the possibility of surface oxidation of $\mathrm{Fe}_{3} \mathrm{O}_{4}$ [63]. De-convolution of the O1s peak (Fig. 3c) show three distinct peaks centered at 532.9, 531.3, and $530.1 \mathrm{eV}$, which are related to the molecular water in the sample or adsorbed on the surface, defects related $\mathrm{OH}$ - group, and lattice oxygen $[64,65]$. The N1s peak (Fig. 3d) is deconvoluted into two components with peaks at 400.1 and $399.2 \mathrm{eV}$, which are assigned to pyrrolic-N (-NH-) and pyridine-N (=N-), respectively [66, 67]. Fig. 3e shows the high-resolution XPS spectrum of Fe $2 \mathrm{p}$ region for $\mathrm{Fe}_{3} \mathrm{O}_{4}$ micro/nanospheres. Besides the main peaks those corresponding to $\mathrm{Fe} 2 \mathrm{p} 3 / 2$ $(710.3 \mathrm{eV})$ and $\mathrm{Fe} 2 \mathrm{p} 1 / 2(723.9 \mathrm{eV})$, a satellite peak situated at $\sim 718.8 \mathrm{eV}$, which is a characteristic peak of $\mathrm{Fe}^{3+}$ in $\gamma-\mathrm{Fe}_{2} \mathrm{O}_{3}$ phase, can be distinguished [63]. The results indicate the surface of $\mathrm{Fe}_{3} \mathrm{O}_{4}$ micro/nanospheres is partly oxidized to $\gamma-\mathrm{Fe}_{2} \mathrm{O}_{3}$. As shown in Fig. 3f, the $\mathrm{O}$ 1s spectrum can be fitted with defects related $\mathrm{OH}-$ group $(530.8 \mathrm{eV})$ and lattice oxygen peak (529.7 $\mathrm{eV}$ ), respectively. The surface area and porous structure of FPys and $\mathrm{Fe}_{3} \mathrm{O}_{4}$ micro/nanospheres were studied by measuring nitrogen adsorption-desorption isotherms at $77 \mathrm{~K}$ (Fig. 4a, b).

The BET surface area for FPys micro/nanospheres is $78.9 \mathrm{~m}^{2} \mathrm{~g}^{-1}$. The corresponding pore size curve confirms the mesopores and micropores size distribution based on the 
Barret-Joyner-Halende (BJH) method. The micropores could be ascribed to the assembly of the primary $\mathrm{Fe}_{3} \mathrm{O}_{4}$ particle with size of sub-10 nm into the yolks (Fig. 2e, g), while the mesopores mainly come from the gap between the $\mathrm{Fe}_{3} \mathrm{O}_{4}$ yolks and PANI shells with loose nature (Fig. 2b-d). For comparison, the surface area of $\mathrm{Fe}_{3} \mathrm{O}_{4}$ micro/nanospheres is $86.5 \mathrm{~m}^{2} \mathrm{~g}^{-1}$, which is a little larger than that of FPys sample. The large surface area and hierarchical microporous/mesoporous pore structures in FPys micro/nanospheres are important for lithium storage, due to the capability of providing extra active sites for the reaction with lithium ions and facilitating rapid ion transport and mass diffusion. It is anticipated that the FPys micro/nanospheres should show good lithium-storage properties.

\subsection{Lithium storage properties}

The lithium storage properties of the samples were investigated by assembling CR 2032 coin-type half cells. Fig. 5a shows the CV curves of FPys electrode for the first three cycles. In the first scan, an obvious reduction peak at $\sim 0.55 \mathrm{~V}$ that assigned to the irreversible conversion from $\mathrm{Fe}_{3} \mathrm{O}_{4}$ to $\mathrm{Fe} / \mathrm{Li}_{2} \mathrm{O}$ is observed $[68,69]$. The corresponding oxidation peak at $\sim 1.86 \mathrm{~V}$ is ascribed to the reaction of metallic iron into $\mathrm{Fe}_{3} \mathrm{O}_{4}[68,69]$. In the following two cycles, the peaks especially reduction peaks shift to higher potential direction, which may due to the irreversible structural change of $\mathrm{Fe}_{3} \mathrm{O}_{4}$ from the spinel to the rock salt type during the cycling [70]. The CV graph for FPcs electrode (Fig. S9) shows the similar electrochemical behavior with that of FPys sample. In the $\mathrm{CV}$ curves of $\mathrm{Fe}_{3} \mathrm{O}_{4}$ micro/nanospheres electrode (Fig. S10), the sharp peak at $\sim 0.61 \mathrm{~V}$ in the anodic sweep and the peak at $\sim 1.66 \mathrm{~V}$ in the cathodic sweep of the first scan are consistent with previous reports $[16,19,20]$. In the second and third scans, the cathodic peak shifts to $\sim 0.76 \mathrm{~V}$, while the anodic peak position does not show obvious change. The galvanostatic charge/discharge 
voltage profiles are measured at at a current density of $100 \mathrm{~mA} \mathrm{~g}^{-1}$ in the voltage range of $0.05-3$ $\mathrm{V}$ (vs. $\mathrm{Li} / \mathrm{Li}^{+}$) at room temperature. Representative voltage profiles for FPcs electrode are shown in Fig. 5b. In the first discharge curve, there are three plateaus $(\sim 1.44 \mathrm{~V}, 0.89 \mathrm{~V}$ and $0.67 \mathrm{~V})$ and a following slope down to the cutoff voltage, which are attributed to three-step lithium ion insertion process and the formation of solid electrolyte interphase (SEI) films, respectively. Similar multistep discharge plateaus in transition metal oxide anodes have also been reported previously $[62,71]$. In the charging process, the lithium ion releasing reaction takes place at a voltage of $\sim 1.5$ V. The first discharge and charge capacities are 1692 and $1182 \mathrm{~mA} \mathrm{~h} \mathrm{~g}^{-1}$, leading to an irreversible capacity loss of $33 \%$. The initial irreversible capacity loss is commonly ascribed to the SEI film formation and some other side reactions.

The typical charge-discharge voltage profiles for FPcs and $\mathrm{Fe}_{3} \mathrm{O}_{4}$ micro/nanosphere electrodes are shown in Fig. S11 and 12, which represent the main characters in FPys electrode. The cycling performance together with the Coulombic efficiency of the FPys, FPcs, and $\mathrm{Fe}_{3} \mathrm{O}_{4}$ micro/nanosphere cells is depicted in Fig. $5 \mathrm{c}$ at a constant current density of $100 \mathrm{~mA} \mathrm{~g}^{-1}$ between 0.05 and $3.0 \mathrm{~V}$ (vs. $\mathrm{Li}^{+} / \mathrm{Li}$ ) up to 50 cycles. It is obvious that FPys cell show the highest lithium storage capacity and the best cycling performance. After 50 cycles, the reversible capacity of FPys cell is $982 \mathrm{~mA} \mathrm{~h} \mathrm{~g}^{-1}$, which is higher than that of FPcs cell (632 mA $\left.\mathrm{h} \mathrm{g}^{-1}\right)$ and $\mathrm{Fe}_{3} \mathrm{O}_{4}$ micro/nanosphere cell $\left(305 \mathrm{~mA} \mathrm{~h} \mathrm{~g}^{-1}\right)$, as well as the theoretical capacity of $\mathrm{Fe}_{3} \mathrm{O}_{4}\left(926 \mathrm{~mA} \mathrm{~h} \mathrm{~g}^{-1}\right)$. Under the same measurement condition, the capacity of pristine PANI is $\sim 38 \mathrm{~mA} \mathrm{~h} \mathrm{~g}^{-1}$ (Fig. S13). This value is comparable with the values reported elsewhere and obviously lower than the theoretical capacity of $\mathrm{Fe}_{3} \mathrm{O}_{4}[72,73]$. Therefor, the contribution of PANI 
addition to the overall specific capacity in FPys cell can be excluded. The extra capacity beyond the theoretical one is mainly attributed to the the formation of polymeric gel-like film on the electrode surface during cycling [74]. Beside this, other reversible side reactions may also enable extra lithium storage and result in additional capacity $[75,76]$. The rate capabilities for the cells were also tested at various current densities between 50 and $1000 \mathrm{~mA} \mathrm{~g}^{-1}$ as shown in Fig. 5d. For FPys cell, the reversible capacity changes from $1092.7 \mathrm{~mA} \mathrm{~h} \mathrm{~g}^{-1}$ to $734.6 \mathrm{~mA} \mathrm{~h} \mathrm{~g}^{-1}$ at the current densities of $50 \mathrm{~mA} \mathrm{~g}^{-1}$ and $1000 \mathrm{~mA} \mathrm{~g}^{-1}$. The capacity returns to $1054.1 \mathrm{~mA} \mathrm{~h} \mathrm{~g}^{-1}$ when the current density decreases back to $50 \mathrm{~mA} \mathrm{~g}^{-1}$. In comparison, the capacities of FPcs and $\mathrm{Fe}_{3} \mathrm{O}_{4}$ micro/nanosphere cells are inferior to that of FPys cell in the studied current density range, highlighting the positive role of PANI addition and yolk-shell structural design in the rate performance enhancement. After cycling test, the FPys electrode maintains the initial morphology and structure as confirmed by TEM observations (Fig. S14), demonstrating the good structural stability of the FPys sample during cycling. The lithium storage properties of FPys cell is also found to be better than or comparable with typical $\mathrm{Fe}_{3} \mathrm{O}_{4}$-based anodes reported by other groups as shown in Table 1.

EIS is further performed to study the lithium ions transfer in the cells after the first cycle (Fig. S15). All the Nyquist plots show an inclined line in the low frequency region and a semicircle in the high to medium frequency region, which are corresponding to the lithium ion diffusion inside the electrodes and the charge-transfer process on the interface between electrolyte and electrode $[77,78]$. The diameter of the semicircle for FPys cell is found to be smaller than those of PFcs and $\mathrm{Fe}_{3} \mathrm{O}_{4}$ micro/nanosphere cells. The results show that the unique yolk-shell structure and PANI 
addition in PFys cell facilitate the charge transfer during charging-discharging process, and result in enhanced rate performance.

Based on the above results, the superior lithium storage properties of PFys sample can be attributed to the synergistic effects of the specially designed yolk-shell micro/nanoarchitectures and conductive PANI addition. First, the porous nature of the yolk $\left(\mathrm{Fe}_{3} \mathrm{O}_{4}\right.$ micro/nanosphere) and the void spaces between the yolk and shell parts increase the contact between electrolyte and electrode, and thus provide more active sites for lithium storage. Second, the PANI shells and the porous structure offer rapid conductive path in the electrode and reduce effective diffusion distance for lithium ions and electrons, respectively. Both are essential to improve the rate capability. Last, the micro/nanoarchitectures with internal void spaces and the flexible PANI shells can accommodate the local volume change and prevent the particle aggregation upon cycling, which are beneficial for keeping the integrity of the electrodes and thus improving the cycling performance.

\subsection{Electromagnetic wave absorption properties}

The electromagnetic wave absorption properties of a material are mainly determined by relative permittivity $\left(\varepsilon_{r}, \varepsilon_{r}=\varepsilon^{\prime}-j \varepsilon^{\prime \prime}\right)$ and permeability $\left(\mu_{r}, \mu_{r}=\mu^{\prime}-j \mu^{\prime \prime}\right)$, in which the real parts of permittivity $\left(\varepsilon^{\prime}\right)$ and permeability $\left(\mu^{\prime}\right)$ are associated with the storage capability of electric and magnetic energy, and the imaginary parts of permittivity $\left(\varepsilon^{\prime \prime}\right)$ and permeability $\left(\mu^{\prime \prime}\right)$ stand for the electric and magnetic losses, respectively. The complex permittivity and permeability of the as-prepared samples were measured in a frequency range of $2.0-18 \mathrm{GHz}$ as summarized in Fig. 6a-d. Relatively small $\varepsilon^{\prime}$ and $\varepsilon^{\prime \prime}$ values are observed for $\mathrm{Fe}_{3} \mathrm{O}_{4}$ micro/nanospheres in the studied frequency range. Specifically, the $\varepsilon^{\prime}$ value decreases from 3.1 at $2.0 \mathrm{GHz}$ to 2.6 at $18.0 \mathrm{GHz}$, and 
the $\varepsilon^{\prime \prime}$ value keeps a constant of $\sim 0.4$, indicating a small dielectric loss of $\mathrm{Fe}_{3} \mathrm{O}_{4}$ micro/nanospheres. In contrast, both $\varepsilon^{\prime}$ and $\varepsilon^{\prime \prime}$ of FPys and FPcs samples perform higher values than those of bare $\mathrm{Fe}_{3} \mathrm{O}_{4}$ micro/nanospheres and possess frequency dependent behavior. For instance, the $\varepsilon^{\prime}$ values of FPys and FPcs samples decrease from 5.8 and 6.7 at $2.0 \mathrm{GHz}$ to 4.1 and 4.6 at $18.0 \mathrm{GHz}$, respectively; while the $\varepsilon^{\prime \prime}$ values decrease from 3.1 and 3.5 at $2.0 \mathrm{GHz}$ to 1.7 and 1.7 at $18.0 \mathrm{GHz}$, respectively. Therefore, the dielectric storage and loss ability for FPys and FPcs composites is much better than that of the bare $\mathrm{Fe}_{3} \mathrm{O}_{4}$ sample. Compared with $\mathrm{Fe}_{3} \mathrm{O}_{4}$ micro/nanospheres, the presence of PANI layer in FPys and FPcs composites induces improved electrical conductivity, strong polarization yielded by polaron-bipolaron and other bound charges, thus leading to high $\varepsilon^{\prime}$ and $\varepsilon^{\prime \prime}$ values [79]. It should be noticed that the $\varepsilon^{\prime}$ value for FPys is smaller than that for FPcs although both samples show comparable composition. The possible reason lies in the air, which exists in the void space of the FPys sample, acts as a effective medium to cut down $\varepsilon^{\prime}$ according to Maxwell-Garnet theory [80]. Moreover, the $\varepsilon^{\prime \prime}$ value of FPcs sample is a little higher than that of FPys sample in the frequency range, which mainly due to the additional interfacial polarization generated at the interfaces between $\mathrm{Fe}_{3} \mathrm{O}_{4}$ micro/nanospheres and PANI shells in the FPcs sample. Relative complex permeability results are shown in Fig. 6c, d, in which the $\mu^{\prime}$ value of $\mathrm{Fe}_{3} \mathrm{O}_{4}$ micro/nanospheres decreases abruptly from 1.2 to 0.8 in the range of $2.0-7.3 \mathrm{GHz}$ and then increases to $\sim 1.1$ over 7.3-18 GHz. Meanwhile, the $\mu^{\prime \prime}$ value of $\mathrm{Fe}_{3} \mathrm{O}_{4}$ micro/nanospheres shows a sharp decrease from 1.0 to 0.1 in the range of $2.0-9.0 \mathrm{GHz}$ and then keeps near zero in the range of 9.0-18.0 GHz. The results confirm that magnetic loss in $\mathrm{Fe}_{3} \mathrm{O}_{4}$ micro/nanospheres is mainly attributed to the natural resonance in GHz range [79, 81]. For pure PANI material, the $\mu^{\prime}$ and $\mu^{\prime \prime}$ values are approximately close to 1 and 0 due to the absence of magnetic components $[79,81]$. 
Therefore, the complex permeabilities of the $\mathrm{Fe}_{3} \mathrm{O}_{4}$ and PANI composting samples (FPys and FPcs) display similar trend as that of bare $\mathrm{Fe}_{3} \mathrm{O}_{4}$ micro/nanospheres, and the amplitude of natural resonance in the composite samples is inferior to the bare $\mathrm{Fe}_{3} \mathrm{O}_{4}$ sample. However, the complex permeabilities in the composite samples can be improved by matching impedance derived magnetic loss together with dielectric loss.

The electromagnetic wave absorption properties can also be deduced by the transmission line theory in terms of measuring $\varepsilon_{r}$ and $\mu_{r}$ [79-81]. According to the theory, the sample thickness $(D)$ is one of the key parameters that influence the reflection loss and responding frequency. Generally, the minimal reflection loss, the absorber thickness and reflection loss intensity over $-10.0 \mathrm{~dB}$ (the absorption efficiency is within the range of $90-100 \%$ ) are the main factors to evaluate the electromagnetic wave absorption performance. Figure 6e, $\mathrm{f}$ display the reflection loss maps against the frequency range of 2.0-18.0 GHz for FPys and $\mathrm{Fe}_{3} \mathrm{O}_{4}$ micro/nanospheres with various $D$ from 1.0 to $5.0 \mathrm{~mm}$ in the paraffin-based composites. It can be seen that the reflection loss values of bare $\mathrm{Fe}_{3} \mathrm{O}_{4}$ sample are all above $-10 \mathrm{~dB}$ in the whole range (Fig. 6e). By contrast, FPys sample possesses obvious enhanced reflection loss intensity (Fig. 6f). The minimum reflection loss of $-46.0 \mathrm{~dB}$ is observed at $7.8 \mathrm{GHz}$ with a thickness of $5.0 \mathrm{~mm}$, and reflection loss values below $-10 \mathrm{~dB}$ are obtained in the $6.3-18.0 \mathrm{GHz}$ range with absorber thicknesses of 1.9-5.0 mm. For the FPcs sample, and the maximum reflection loss achieves $-32.4 \mathrm{~dB}$ at $7.0 \mathrm{GHz}$ with a thickness of $5.0 \mathrm{~mm}$ (Fig. S16). It should be noted that in the map of FPys, the bandwidth over $-10.0 \mathrm{~dB}$ is broadened and the reflection loss intensity is enhanced when comparing to FPcs sample, suggesting the electromagnetic absorption properties of FPys have been improved. 
Dielectric loss factor $\left(\tan \delta_{\varepsilon}=\varepsilon^{\prime} / \varepsilon^{\prime \prime}\right)$ and magnetic loss factor $\left(\tan \delta_{\mu}=\mu^{\prime} / \mu^{\prime \prime}\right)$ are the main loss mechanisms for incident electromagnetic waves. The $\tan \delta_{\varepsilon}$ and $\tan \delta_{\mu}$ for the samples are plotted in Fig. $6 \mathrm{~g}$, h. The small dielectric loss factor in $\mathrm{Fe}_{3} \mathrm{O}_{4}$ micro/nanospheres confirms the negligible contribution of dielectric loss in electromagnetic wave absorption. The mean values of $\tan \delta_{\varepsilon}$ for the FPys and FPcs samples are larger than that of the bare $\mathrm{Fe}_{3} \mathrm{O}_{4}$. The enhanced dielectric loss in FPys should be attributed to the specially designed yolk-shell structure, which is favorable for the multiple reflection of incident electromagnetic waves $[82,83]$. The magnetic loss factor $\tan \delta_{\mu}$ of the samples shows the similar trend with $\mu^{\prime \prime}$. The results are benefit for improving impedance matching and showing highly dissipation efficiency.

The enhanced electromagnetic parameters and matching performance are attributed to the unique yolk-shell structure. First, multi-reflection and scattering between the $\mathrm{Fe}_{3} \mathrm{O}_{4}$ core and PANI shell promotes the energy consumption of incident electromagnetic waves. Second, the plentiful interfaces between $\mathrm{Fe}_{3} \mathrm{O}_{4}$, air and PANI give rise to interfacial polarization and relaxation, which are important to provide additional electromagnetic wave energy attenuate.

\section{Conclusions}

FPys micro/nanostructures constituted by $\mathrm{Fe}_{3} \mathrm{O}_{4} / \mathrm{PANI}$ composites with yolk-shell configuration were successfully synthesized by a facile silica-assisted in-situ polymerization and subsequent etching method. The as-prepared sample was demonstrated to show excellent bifunctional properties when used as LIB anodes and electromagnetic wave absorbers. Specifically, the FPys cell showed a high reversible capacity of $\sim 982 \mathrm{~mA} \mathrm{~h} \mathrm{~g}^{-1}$ after 50 cycles at a current density of $100 \mathrm{~mA} \mathrm{~g}^{-1}$. A capacity of $734.6 \mathrm{~mA} \mathrm{~h} \mathrm{~g}^{-1}$ was still achieved at $1000 \mathrm{~mA} \mathrm{~g}^{-1}$. The FPys sample also shows an enhancement of dielectric loss and magnetic loss at the frequency range of 
2.0-18 GHz. The minimum reflection loss of $-46.0 \mathrm{~dB}$ is observed at $7.8 \mathrm{GHz}$ with a thickness of $5.0 \mathrm{~mm}$, and reflection loss values below $-10 \mathrm{~dB}$ are obtained in the $6.3-18.0 \mathrm{GHz}$ range with absorber thicknesses of 1.9-5.0 $\mathrm{mm}$. The bifunctional properties can be attributed to the unique hierarchical micro/nanostructures. The present route to yolk-shell $\mathrm{Fe}_{3} \mathrm{O}_{4} / \mathrm{PANI}$ composites can be extended to synthesis other multifunctional materials.

\section{Acknowledgments}

The authors would like to appreciate the financial supports from Chinese National Natural Science Foundation $(51401114,51701063)$. 


\section{References}

[1] A.M. Omer, Energy, environment and sustainable development, Renew. Sust. Energy Rev. 12 (2008) 2265-2300.

[2] J. Lu, Z. Chen, Z. Ma, F. Pan, L.A. Curtiss, K. Amine, The role of nanotechnology in the development of battery materials for electric vehicles, Nat. Nanotechnol. 11 (2016) 1031-1038.

[3] J.D. Boice, R.E. Tarone, Cell phones, cancer, and children, J. Natl. Cancer. Inst. 103 (2011) $1211-1213$.

[4] Z. Chen, C. Xu, C. Ma, W. Ren, H.-M. Cheng, Lightweight and flexible graphene foam composites for high-performance electromagnetic interference shielding, Adv. Mater. 25 (2013) $1296-1300$

[5] J.B. Goodenough, K.-S. Park, The li-ion rechargeable battery: a perspective, J. Am. Chem. Soc. 135 (2013) 1167-1176.

[6] C.M. Hayner, X. Zhao, H.H. Kung, Materials for rechargeable lithium-ion batteries, Annu. Rev. Chem. Biomol. 3 (2012) 445-471.

[7] C.M. Watts, X. Liu, W.J. Padilla, Metamaterial electromagnetic wave absorbers, Adv. Mater. 24 (2012) OP98-OP120.

[8] T.-H. Kim, J.-S. Park, S.K. Chang, S. Choi, J.H. Ryu, H.-K. Song, The Current move of lithium ion batteries towards the next phase, Adv. Energy Mater. 2 (2012) 860-872.

[9] V. Etacheri, R. Marom, R. Elazari, G. Salitra, D. Aurbach, Challenges in the development of advanced Li-ion batteries: a review, Energy Environ. Sci. 4 (2011) 3243-3262.

[10] Y.P. Wu, E. Rahm, R. Holze, Carbon anode materials for lithium ion batteries, J. Power Sources 114 (2003) 228-236. 
[11] M.N. Obrovac, V.L. Chevrier, Alloy negative electrodes for Li-ion batteries, Chem. Rev. 114 (2014) 11444-11502.

[12] H.B. Wu, J.S. Chen, H.H. Hng, X.W. (David) Lou, Nanostructured metal oxide-based materials as advanced anodes for lithium-ion batteries, Nanoscale 4 (2012) 2526-2542.

[13] X. Xu, W. Liu, Y. Kim, J. Cho, Nanostructured transition metal sulfides for lithium ion batteries: Progress and challenges, Nano Today 9 (2014) 604-630.

[14] S. Goriparti, E. Miele, F. De Angelis, E. Di Fabrizio, R. Proietti Zaccaria, C. Capiglia, Review on recent progress of nanostructured anode materials for Li-ion batteries, J. Power Sources. 257 (2014) 421-443.

[15] P.L. Taberna, S. Mitra, P. Poizot, P. Simon, J.-M. Tarascon, High rate capabilities $\mathrm{Fe}_{3} \mathrm{O}_{4}$-based $\mathrm{Cu}$ nano-architectured electrodes for lithium-ion battery applications, Nat. Mater. 5 (2006) $567-573$.

[16] Q.Q. Xiong, J.P. Tu, Y. Lu, J. Chen, Y.X. Yu, Y.Q. Qiao, X.L. Wang, C.D. Gu, Synthesis of hierarchical hollow-structured single-crystalline magnetite $\left(\mathrm{Fe}_{3} \mathrm{O}_{4}\right)$ microspheres: the highly powerful storage versus lithium as an anode for lithium ion batteries, J. Phys. Chem. C 116 (2012) 6495-6502.

[17] S. Mitra, P. Poizot, A. Finke, J.-M. Tarascon, Growth and electrochemical characterization versus lithium of $\mathrm{Fe}_{3} \mathrm{O}_{4}$ electrodes made by electrodeposition, Adv. Funct. Mater. 16 (2006) 2281-2287.

[18] L. Shen, H. Song, G. Yang, C. Wang, Hollow ball-in-ball $\mathrm{Co}_{x} \mathrm{Fe}_{3-\mathrm{x}} \mathrm{O}_{4}$ nanostructures: high-performance anode materials for lithium-ion battery, ACS Appl. Mater. Interfaces 7 (2015) 11063-11068. 
[19] X. Wang, Y. Liu, H. Arandiyan, H. Yang, L. Bai, J. Mujtaba, Q. Wang, S. Liu, H. Sun, Uniform $\mathrm{Fe}_{3} \mathrm{O}_{4}$ microflowers hierarchical structures assembled with porous nanoplates as superior anode materials for lithium-ion batteries, Appl. Surf. Sci. 389 (2016) 240-246.

[20] M. Lübke, N.M. Makwana, R. Gruar, C. Tighe, D. Brett, P. Shearing, Z. Liu, J.A. Darr, High capacity nanocomposite $\mathrm{Fe}_{3} \mathrm{O}_{4} / \mathrm{Fe}$ anodes for Li-ion batteries, J. Power Sources 291 (2015) $102-107$.

[21] L. Pan, X.-D. Zhu, X.-M. Xie, Y.-T. Liu, Smart hybridization of $\mathrm{TiO}_{2}$ nanorods and $\mathrm{Fe}_{3} \mathrm{O}_{4}$ nanoparticles with pristine graphene nanosheets: hierarchically nanoengineered ternary heterostructures for high-rate lithium storage, Adv. Funct. Mater. 25 (2015) 3341-3350.

[22] S. Petnikota, H. Maseed, V.V.S.S. Srikanth, M.V. Reddy, S. Adams, M. Srinivasan, B.V.R. Chowdari, Experimental elucidation of a graphenothermal reduction mechanism of $\mathrm{Fe}_{2} \mathrm{O}_{3}$ : an enhanced anodic behavior of an exfoliated reduced graphene oxide/ $\mathrm{Fe}_{3} \mathrm{O}_{4}$ composite in Li-ion batteries, J. Phys. Chem. C 121 (2017) 3778-3789.

[23] Y. Yang, J. Li, D. Chen, J. Zhao, A Facile Electrophoretic deposition route to the $\mathrm{Fe}_{3} \mathrm{O}_{4} / \mathrm{CNTs} / \mathrm{rGO}$ composite electrode as a binder-free anode for lithium ion battery, ACS Appl. Mater. Interfaces 8 (2016) 26730-26739.

[24] L. Yang, G. Guo, H. Sun, X. Shen, J. Hu, A. Dong, D. Yang, Ionic liquid as the C and N sources to prepare yolk-shell $\mathrm{Fe}_{3} \mathrm{O}_{4} @ \mathrm{~N}$-doped carbon nanoparticles and its high performance in lithium-ion battery, Electrochim. Acta 190 (2016) 797-803.

[25] M. Ren, M. Yang, W. Liu, M. Li, L. Su, C. Qiao, X. Wu, H. Ma, Ultra-small $\mathrm{Fe}_{3} \mathrm{O}_{4}$ nanocrystals decorated on 2D graphene nanosheets with excellent cycling stability as anode materials for lithium ion batteries, Electrochim. Acta 194 (2016) 219-227. 
[26] J. He, S. Zhao, Y. Lian, M. Zhou, L. Wang, B. Ding, S. Cui, Graphene-doped carbon/Fe $\mathrm{O}_{4}$ porous nanofibers with hierarchical band construction as high-performance anodes for lithium-ion batteries, Electrochim. Acta 229 (2017) 306-315.

[27] J. Jiao, W. Qiu, J. Tang, L. Chen, L. Jing, Synthesis of well-defined $\mathrm{Fe}_{3} \mathrm{O}_{4}$ nanorods/N-doped graphene for lithium-ion batteries, Nano Res. 9 (2016) 1256-1266.

[28] Y. Zuo, G. Wang, J. Peng, G. Li, Y. Ma, F. Yu, B. Dai, X. Guo, C.-P. Wong, Hybridization of graphene nanosheets and carbon-coated hollow $\mathrm{Fe}_{3} \mathrm{O}_{4}$ nanoparticles as a high-performance anode material for lithium-ion batteries, J. Mater. Chem. A 4 (2016) 2453-2460.

[29] J. Liu, X. Xu, R. Hu, L. Yang, M. Zhu, Uniform hierarchical $\mathrm{Fe}_{3} \mathrm{O}_{4} @$ polypyrrole nanocages for superior lithium ion battery anodes, Adv. Energy Mater. 6 (2016) 1600256.

[30] Y. Zhang, Y. Li, H. Li, Y. Zhao, F. Yin, Z. Bakenov, Electrochemical performance of carbon-encapsulated $\mathrm{Fe}_{3} \mathrm{O}_{4}$ nanoparticles in lithium-ion batteries: morphology and particle size effects, Electrochim. Acta 216 (2016) 475-483.

[31] X. Sun, G. Gao, D. Yan, C. Feng, Synthesis and electrochemical properties of $\mathrm{Fe}_{3} \mathrm{O}_{4} @ \mathrm{MOF}$ core-shell microspheres as an anode for lithium ion battery application, Appl. Surf. Sci. 405 (2017) $52-59$.

[32] S. Chen, R. Zhou, Y. Chen, Y. Fu, P. Li, Y. Song, L. Wang, Carbon-covered $\mathrm{Fe}_{3} \mathrm{O}_{4}$ hollow cubic hierarchical porous composite as the anode material for lithium-ion batteries, J. Nanopart. Res. 19 (2017) 127.

[33] Z. Liu, X.-Y. Yu, U. Paik, Etching-in-a-Box: A novel strategy to synthesize unique yolk-shelled $\mathrm{Fe}_{3} \mathrm{O}_{4} @$ carbon with an ultralong cycling life for lithium storage, Adv. Energy Mater. 6 (2016) 1502318. 
[34] M. Liu, H. Jin, E. Uchaker, Z. Xie, Y. Wang, G. Cao, S. Hou, J. Li, One-pot synthesis of in-situ carbon-coated $\mathrm{Fe}_{3} \mathrm{O}_{4}$ as a long-life lithium-ion battery anode, Nanotechnology 28 (2017) 155603.

[35] S. Li, M. Wang, Y. Luo, J. Huang, Bio-Inspired hierarchical nanofibrous $\mathrm{Fe}_{3} \mathrm{O}_{4}-\mathrm{TiO}_{2}$-carbon composite as a high-performance anode material for lithium-ion batteries, ACS Appl. Mater. Interfaces 8 (2016) 17343-17351.

[36] C. He, S. Wu, N. Zhao, C. Shi, E. Liu, J. Li, Carbon-encapsulated $\mathrm{Fe}_{3} \mathrm{O}_{4}$ nanoparticles as a high-rate lithium ion battery anode material, ACS Nano 7 (2013) 4459-4469.

[37] J. Luo, J. Liu, Z. Zeng, C.F. Ng, L. Ma, H. Zhang, J. Lin, Z. Shen, H.J. Fan, Three-dimensional graphene foam supported $\mathrm{Fe}_{3} \mathrm{O}_{4}$ lithium battery anodes with long cycle life and high rate capability, Nano Lett. 13 (2013) 6136-6143.

[38] Y.-Z. Long, M.-M. Li, C. Gu, M. Wan, J.-L. Duvail, Z. Liu, Z. Fan, Recent advances in synthesis, physical properties and applications of conducting polymer nanotubes and nanofibers, Prog. Polym. Sci. 36 (2011) 1415-1442.

[39] H. Wang, J. Lin, Z.X. Shen, Polyaniline (PANi) based electrode materials for energy storage and conversion, J. Sci. Adv. Mate. Dev. 1 (2016) 225-255.

[40] S. Wang, L. Hu, Y. Hu, S. Jiao, Conductive polyaniline capped $\mathrm{Fe}_{2} \mathrm{O}_{3}$ composite anode for high rate lithium ion batteries, Mater. Chem. Phys. 146 (2014) 289-294.

[41] J.-M. Jeong, B.G. Choi, S.C. Lee, K.G. Lee, S.-J. Chang, Y.-K. Han, Y.B. Lee, H.U. Lee, S. Kwon, G. Lee, C.-S. Lee, Y.S. Huh, Hierarchical hollow spheres of $\mathrm{Fe}_{2} \mathrm{O}_{3} @$ polyaniline for lithium ion battery anodes, Adv. Mater. 25 (2013) 6250-6255.

[42] Y. Wang, H. Wei, J. Wang, J. Liu, J. Guo, X. Zhang, B.L. Weeks, T.D. Shen, S. Wei, Z. Guo, 
Electropolymerized polyaniline/manganese iron oxide hybrids with an enhanced color switching response and electrochemical energy storage, J. Mater. Chem. A 3 (2015) 20778-20790.

[43] L.K. Joy, V. Sooraj, U.S. Sajeev, S.S. Nair, T.N. Narayanan, N. Sethulakshmi, P.M. Ajayan, M.R. Anantharaman, Large enhanced dielectric permittivity in polyaniline passivated core-shell nano magnetic iron oxide by plasma polymerization, Appl. Phys. Lett. 104 (2014) 121603.

[44] Y. Sun, F. Xiao, X. Liu, C. Feng, C. Jin, Preparation and electromagnetic wave absorption properties of core-shell structured $\mathrm{Fe}_{3} \mathrm{O}_{4}$-polyaniline nanoparticles, RSC Adv. 3 (2013) $22554-22559$.

[45] S. Xuan, Y.-X.J. Wang, K.C.-F. Leung, K. Shu, Synthesis of $\mathrm{Fe}_{3} \mathrm{O}_{4} @$ polyaniline core/shell microspheres with well-defined blackberry-like morphology, J. Phys. Chem. C 112 (2008) 18804-18809.

[46] J. Huang, Q. Li, D. Li, Y. Wang, L. Dong, H. Xie, J. Wang, C. Xiong, Flexible nanoclusters of $\mathrm{Fe}_{3} \mathrm{O}_{4}$ nanocrystal-embedded polyaniline by macromolecule-induced self-assembly, Langmuir 29 (2013) 10223-10228.

[47] J. Liu, R. Che, H. Chen, F. Zhang, F. Xia, Q. Wu, M. Wang, Microwave absorption enhancement of multifunctional composite microspheres with spinel $\mathrm{Fe}_{3} \mathrm{O}_{4}$ cores and anatase $\mathrm{TiO}_{2}$ shells, Small 8 (2012) 1214-1221.

[48] Y.-H. Chen, Z.-H. Huang, M.-M. Lu, W.-Q. Cao, J. Yuan, D.-Q. Zhang, M.-S. Cao, 3D Fe $\mathrm{O}_{4}$ nanocrystals decorating carbon nanotubes to tune electromagnetic properties and enhance microwave absorption capacity, J. Mater. Chem. A 3 (2015) 12621-12625.

[49] M.-S. Cao, J. Yang, W.-L. Song, D.-Q. Zhang, B. Wen, H.-B. Jin, Z.-L. Hou, J. Yuan, Ferroferric oxide/multiwalled carbon nanotube vs polyaniline/ferroferric oxide/multiwalled carbon 
nanotube multiheterostructures for highly effective microwave absorption, ACS Appl. Mater. Interfaces 4 (2012) 6949-6956.

[50] Y. Li, T. Wu, K. Jiang, G. Tong, K. Jin, N. Qian, L. Zhao, T. Lv, Mn ${ }^{2+}$ induced structure evolution and dual-frequency microwave absorption of $\mathrm{Mn}_{\mathrm{x}} \mathrm{Fe}_{3-\mathrm{x}} \mathrm{O}_{4}$ hollow/porous spherical chains made by a one-pot solvothermal approach, J. Mater. Chem. C 4 (2016) 7119-7129.

[51] G. Tong, Y. Liu, T. Cui, Y. Li, Y. Zhao, J. Guan, Tunable dielectric properties and excellent microwave absorbing properties of elliptical $\mathrm{Fe}_{3} \mathrm{O}_{4}$ nanorings, Appl. Phys. Lett. 108 (2016) 072905.

[52] W. Stöber, A. Fink, E. Bohn, Controlled growth of monodisperse silica spheres in the micron size range, Journal of Colloid and Interface Science 26 (1968) 62-69.

[53] S.-H. Wu, C.-Y. Mou, H.-P. Lin, Synthesis of mesoporous silica nanoparticles, Chem. Soc. Rev. 42 (2013) 3862-3875.

[54] A.M. Nicolson, G.F. Ross, Measurement of the intrinsic properties of materials by time-domain techniques, IEEE Trans. Instrum. Meas. 19 (1970) 377-382.

[55] Y. Waseda, E. Matsubara, K. Shinoda, X-ray diffraction crystallography: introduction, examples and solved problems, Springer Science \& Business Media, 2011, p. 127.

[56] C. Vallés, P. Jiménez, E. Muñoz, A.M. Benito, W.K. Maser, Simultaneous reduction of graphene oxide and polyaniline: doping-assisted formation of a solid-state charge-transfer complex, J. Phys. Chem. C 115 (2011) 10468-10474.

[57] G. Gnana kumar, C.J. Kirubaharan, S. Udhayakumar, C. Karthikeyan, K.S. Nahm, Conductive polymer/graphene supported platinum nanoparticles as anode catalysts for the extended power generation of microbial fuel cells, Ind. Eng. Chem. Res. 53 (2014) 16883-16893. 
[58] G. Xu, D. Xu, J. Zhang, K. Wang, Z. Chen, J. Chen, Q. Xu, Controlled fabrication of PANI/CNF hybrid films: Molecular interaction induced various micromorphologies and electrochemical properties, J. Colloid Interf. Sci. 411 (2013) 204-212.

[59] A. Mukhopadhyay, N. Joshi, K. Chattopadhyay, G. De, A facile synthesis of PEG-coated magnetite $\left(\mathrm{Fe}_{3} \mathrm{O}_{4}\right)$ nanoparticles and their prevention of the reduction of cytochrome C, ACS Appl. Mater. Interfaces 4 (2012) 142-149.

[60] A. Jafari, S. Farjami Shayesteh, M. Salouti, K. Boustani, Effect of annealing temperature on magnetic phase transition in $\mathrm{Fe}_{3} \mathrm{O}_{4}$ nanoparticles, J. Magn. Magn. Mater. 379 (2015) 305-312.

[61] S. Nasrazadani, A. Raman, The application of infrared spectroscopy to the study of rust systems-II. Study of cation deficiency in magnetite $\left(\mathrm{Fe}_{3} \mathrm{O}_{4}\right)$ produced during its transformation to maghemite $\left(\gamma-\mathrm{Fe}_{2} \mathrm{O}_{3}\right)$ and hematite $\left(\alpha-\mathrm{Fe}_{2} \mathrm{O}_{3}\right)$, Corros. Sci. 34 (1993) 1355-1365.

[62] X. Meng, Y. Xu, X. Sun, J. Wang, L. Xiong, X. Du, S. Mao, Graphene oxide sheets-induced growth of nanostructured $\mathrm{Fe}_{3} \mathrm{O}_{4}$ for a high-performance anode material of lithium ion batteries, $\mathrm{J}$. Mater. Chem. A 3 (2015) 12938-12946.

[63] X.-D. Zhu, K.-X. Wang, D.-J. Yan, S.-R. Le, R.-J. Ma, K.-N. Sun, Y.-T. Liu, Creating a synergistic interplay between tubular $\mathrm{MoS} 2$ and particulate $\mathrm{Fe}_{3} \mathrm{O}_{4}$ for improved lithium storage, Chem. Commun. 51 (2015) 11888-11891.

[64] L. Li, Y. Li, S. Gao, N. Koshizaki, Ordered $\mathrm{Co}_{3} \mathrm{O}_{4}$ hierarchical nanorod arrays: tunable superhydrophilicity without UV irradiation and transition to superhydrophobicity, J. Mater. Chem. 19 (2009) 8366-8371.

[65] J. Huang, F. Fang, G. Huang, H. Sun, J. Zhu, R. Yu, Engineering the surface of rutile $\mathrm{TiO}_{2}$ nanoparticles with quantum pits towards excellent lithium storage, RSC Adv. 6 (2016) 
$66197-66203$.

[66] R.L. Arechederra, K. Artyushkova, P. Atanassov, S.D. Minteer, Growth of phthalocyanine doped and undoped nanotubes using mild synthesis conditions for development of novel oxygen reduction catalysts, ACS Appl. Mater. Interfaces 2 (2010) 3295-3302.

[67] F. Jaouen, J. Herranz, M. Lefèvre, J.-P. Dodelet, U.I. Kramm, I. Herrmann, P. Bogdanoff, J. Maruyama, T. Nagaoka, A. Garsuch, J.R. Dahn, T. Olson, S. Pylypenko, P. Atanassov, E.A. Ustinov, Cross-laboratory experimental study of non-noble-metal electrocatalysts for the oxygen reduction reaction, ACS Appl. Mater. Interfaces 1 (2009) 1623-1639.

[68] B. Jin, A.-H. Liu, G.-Y. Liu, Z.-Z. Yang, X.-B. Zhong, X.-Z. Ma, M. Yang, H.-Y. Wang, $\mathrm{Fe}_{3} \mathrm{O}_{4}$-pyrolytic graphite oxide composite as an anode material for lithium secondary batteries, Electrochim. Acta 90 (2013) 426-432.

[69] H. Liu, G. Wang, J. Wang, D. Wexler, Magnetite/carbon core-shell nanorods as anode materials for lithium-ion batteries, Electrochem. Commun. 10 (2008) 1879-1882.

[70] L. Shen, H. Song, H. Cui, X. Wen, X. Wei, C. Wang, $\mathrm{Fe}_{3} \mathrm{O}_{4}$-carbon nanocomposites via a simple synthesis as anode materials for rechargeable lithium ion batteries, CrystEngComm 15 (2013) 9849-9854.

[71] K. He, S. Zhang, J. Li, X. Yu, Q. Meng, Y. Zhu, E. Hu, K. Sun, H. Yun, X.-Q. Yang, Y. Zhu, H. Gan, Y. Mo, E.A. Stach, C.B. Murray, D. Su, Visualizing non-equilibrium lithiation of spinel oxide via in situ transmission electron microscopy, Nat. Commun. 7 (2016) 11441.

[72] Q. Zhou, L. Liu, Z. Huang, L. Yi, X. Wang, G. Cao, $\mathrm{Co}_{3} \mathrm{~S}_{4} @$ polyaniline nanotubes as high-performance anode materials for sodium ion batteries, J. Mater. Chem. A 4 (2016) $5505-5516$. 
[73] M. Feng, J. Tian, H. Xie, Y. Kang, Z. Shan, Nano-silicon/polyaniline composites with an enhanced reversible capacity as anode materials for lithium ion batteries, J. Solid State Electrochem. 19 (2015) 1773-1782.

[74] S. Laruelle, S. Grugeon, P. Poizot, M. Dollé, L. Dupont, J.-M. Tarascon, On the origin of the extra electrochemical capacity displayed by MO/Li cells at low potential, J. Electrochem. Soc. 149 (2002) A627-A634.

[75] Y.-Y. Hu, Z. Liu, K.-W. Nam, O.J. Borkiewicz, J. Cheng, X. Hua, M.T. Dunstan, X. Yu, K.M. Wiaderek, L.-S. Du, K.W. Chapman, P.J. Chupas, X.-Q. Yang, C.P. Grey, Origin of additional capacities in metal oxide lithium-ion battery electrodes, Nat. Mater. 12 (2013) 1130-1136.

[76] A. Ponrouch, P.-L. Taberna, P. Simon, M.R. Palacín, On the origin of the extra capacity at low potential in materials for Li batteries reacting through conversion reaction, Electrochim. Acta 61 (2012) 13-18.

[77] Y. Liu, Z. Cheng, H. Sun, H. Arandiyan, J. Li, M. Ahmad, Mesoporous $\mathrm{Co}_{3} \mathrm{O}_{4}$ sheets/3D graphene networks nanohybrids for high-performance sodium-ion battery anode, J. Power Sources 273 (2015) 878-884.

[78] H. Sun, Y. Liu, Y. Yu, M. Ahmad, D. Nan, J. Zhu, Mesoporous $\mathrm{Co}_{3} \mathrm{O}_{4}$ nanosheets-3D graphene networks hybrid materials for high-performance lithium ion batteries, Electrochim. Acta 118 (2014) 1-9.

[79] C. Cui, Y. Du, T. Li, X. Zheng, X. Wang, X. Han, P. Xu, Synthesis of electromagnetic functionalized $\mathrm{Fe}_{3} \mathrm{O}_{4}$ microspheres/polyaniline composites by two-step oxidative polymerization, J. Phys. Chem. B 116 (2012) 9523-9531.

[80] J. C. Maxwcll-Garnctt, Colours in metal glasses and in metal films, Trans. R. Soc. 
London 203 (1904) 385-420.

[81] B. Zhang, Y. Du, P. Zhang, H. Zhao, L. Kang, X. Han, P. Xu, Microwave absorption enhancement of $\mathrm{Fe}_{3} \mathrm{O}_{4} /$ polyaniline core/shell hybrid microspheres with controlled shell thickness, J. Appl. Polym. Sci. 130 (2013) 1909-1916.

[82] C. Tian, Y. Du, C. Cui, Z. Deng, J. Xue, P. Xu, R. Qiang, Y. Wang, X. Han, Synthesis and microwave absorption enhancement of yolk-shell $\mathrm{Fe}_{3} \mathrm{O}_{4} @ \mathrm{C}$ microspheres, J. Mater. Sci. 52 (2017) 6349-6361.

[83] B. Zhao, X. Guo, W. Zhao, J. Deng, G. Shao, B. Fan, Z. Bai, R. Zhang, Yolk-shell Ni@ $\mathrm{SnO}_{2}$ composites with a designable interspace to improve the electromagnetic wave absorption properties, ACS Appl. Mater. Interfaces 8 (2016) 28917-28925. 


\section{Figure and Table Captions}

Fig. 1. XRD patterns of the as-prepared $\mathrm{FPys}$ (red), $\mathrm{Fe}_{3} \mathrm{O}_{4}$ micro/nanospheres (black), and the standard pattern of $\mathrm{Fe}_{3} \mathrm{O}_{4}$ phase.

Fig. 2. (a) Low- and (b) high- magnification FESEM images, (c-e) low- and (g) highmagnification TEM images, (inset in c) EDX and (f) SAED patterns, and (h, i) HRTEM images of the FPys micro/nanospheres. The white arrows in (b-e) show the existence of gaps between the $\mathrm{Fe}_{3} \mathrm{O}_{4}$ yolks and PANI shells.

Fig. 3. (a) XPS survey spectrum and (b-d) high-resolution XPS spectra of the Fe 2p, O 1s, and N 1s regions of the FPys micro/nanospheres; (e, f) high-resolution XPS spectra of the Fe 2p, and $\mathrm{O} 1 \mathrm{~s}$ regions of the $\mathrm{Fe}_{3} \mathrm{O}_{4}$ micro/nanospheres.

Fig. 4. (a) Nitrogen adsorption-desorption isotherms and (b) the corresponding pore size distribution curves of the $\mathrm{FPys}$ (red) and $\mathrm{Fe}_{3} \mathrm{O}_{4}$ micro/nanospheres (black).

Fig. 5. (a) CV profiles of the FPys micro/nanospheres electrode during the first three cycles at a scan rate of $0.5 \mathrm{mV} \mathrm{s}^{-1}$ between 0.05 and $3 \mathrm{~V}$ (vs. $\mathrm{Li}^{+} / \mathrm{Li}$ ); (b) galvanostatic charge/discharge voltage profiles for the first three cycles between 0.05 and $3 \mathrm{~V}\left(\mathrm{vs} . \mathrm{Li}^{+} / \mathrm{Li}\right.$ ) at a current density of $100 \mathrm{~mA} \mathrm{~g}^{-1}$; (c) Cycling performance of FPys (red), FPcs (blue), and $\mathrm{Fe}_{3} \mathrm{O}_{4}$ (black) micro/nanospheres electrodes at a constant current rate of $100 \mathrm{~mA} \mathrm{~g}{ }^{-1}$ between 0.05 and $3 \mathrm{~V}$ (vs. $\mathrm{Li}^{+} / \mathrm{Li}$ ); (d) rate capability of $\mathrm{FPys}$ (red), $\mathrm{FP} c s$ (blue), and $\mathrm{Fe}_{3} \mathrm{O}_{4}$ (black) micro/nanospheres electrodes at different current rates between $50 \mathrm{~mA} \mathrm{~g}^{-1}$ and 1000 $\mathrm{mA} \mathrm{g}^{-1}$ in the voltage window of $0.05-3 \mathrm{~V}\left(\mathrm{vs} . \mathrm{Li}^{+} / \mathrm{Li}\right)$.

Fig. 6. Frequency dependent (a) real $\left(\varepsilon^{\prime}\right)$, (b) imaginary $\left(\varepsilon^{\prime \prime}\right)$ parts of permittivity, and (c) real $\left(\mu^{\prime}\right)$, (d) imaginary $\left(\mu^{\prime \prime}\right)$ parts of complex permeability of FPys, FPcs, and $\mathrm{Fe}_{3} \mathrm{O}_{4}$ 
micro/nanospheres; reflection loss maps of (e) $\mathrm{Fe}_{3} \mathrm{O}_{4}$ micro/nanosphers and (f) FPys in the frequency range of $2.0-18.0 \mathrm{GHz}$ with varied absorber thickness from 1.0 to $5.0 \mathrm{~mm}$; $(\mathrm{g})$ dielectric loss factor and (h) magnetic loss factor of FPys, FPcs, and $\mathrm{Fe}_{3} \mathrm{O}_{4}$ micro/nanospheres.

Scheme 1. Schematic illustration of the formation process of FPys micro/nanospheres; the bifunctional principle of the FPys micro/nanospheres. 


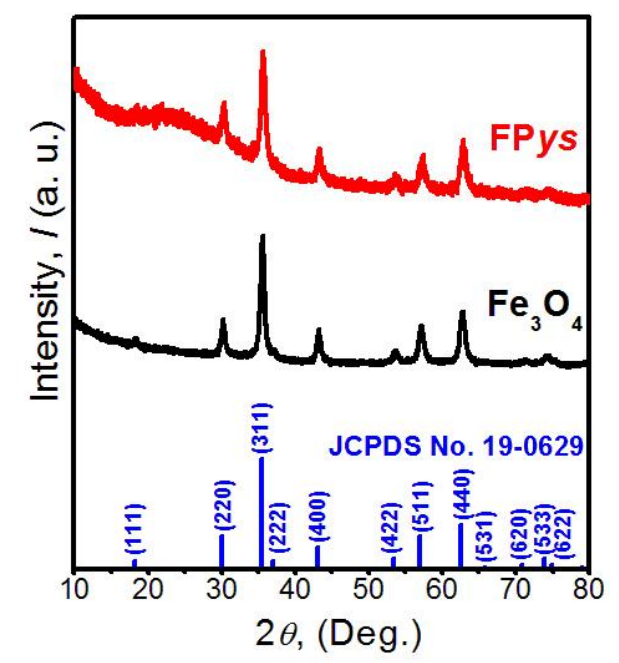

Fig. 1. XRD patterns of the as-prepared $\mathrm{FPys}$ (red), $\mathrm{Fe}_{3} \mathrm{O}_{4}$ micro/nanospheres (black), and the standard pattern of $\mathrm{Fe}_{3} \mathrm{O}_{4}$ phase. 




Fig. 2. (a) Low- and (b) high- magnification FESEM images, (c-e) low- and (g) highmagnification TEM images, (inset in c) EDX and (f) SAED patterns, and (h, i) HRTEM images of the FPys micro/nanospheres. The white arrows in (b-e) show the existence of gaps between the $\mathrm{Fe}_{3} \mathrm{O}_{4}$ yolks and PANI shells. 

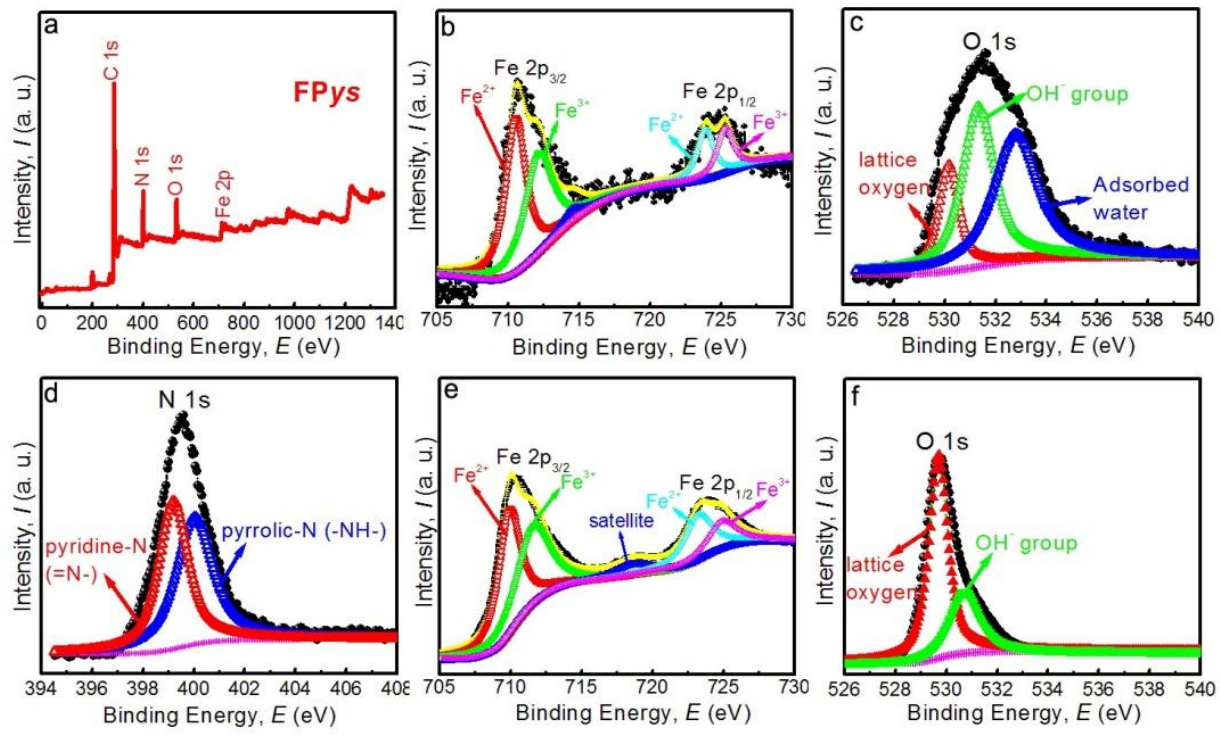

Fig. 3. (a) XPS survey spectrum and (b-d) high-resolution XPS spectra of the Fe 2p, O 1s, and N

1s regions of the FPys micro/nanospheres; (e, f) high-resolution XPS spectra of the Fe 2p, and O

1s regions of the $\mathrm{Fe}_{3} \mathrm{O}_{4}$ micro/nanospheres. 

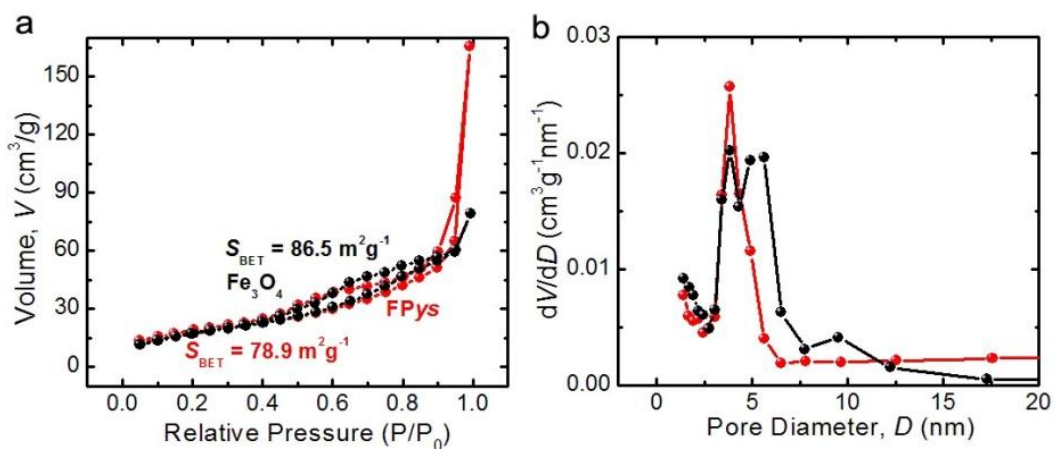

Fig. 4. (a) Nitrogen adsorption-desorption isotherms and (b) the corresponding pore size distribution curves of the $\mathrm{FPys}$ (red) and $\mathrm{Fe}_{3} \mathrm{O}_{4}$ micro/nanospheres (black). 

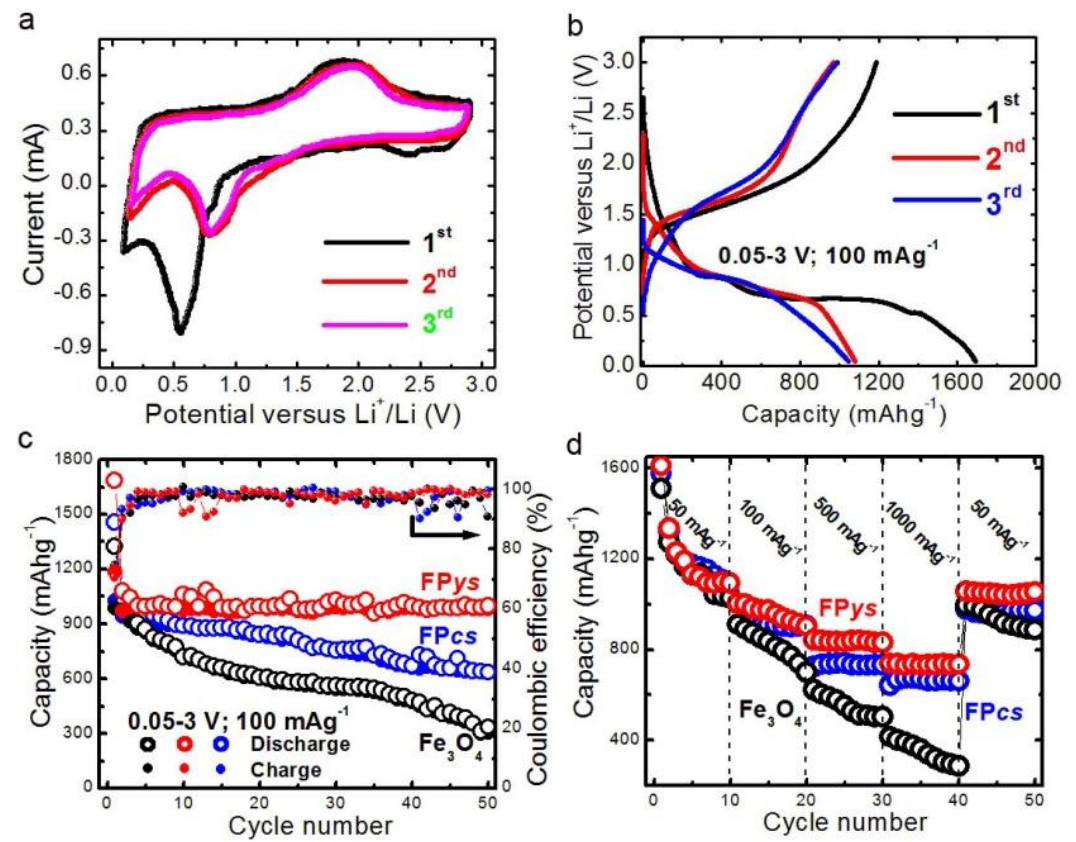

Fig. 5. (a) CV profiles of the FPys micro/nanospheres electrode during the first three cycles at a

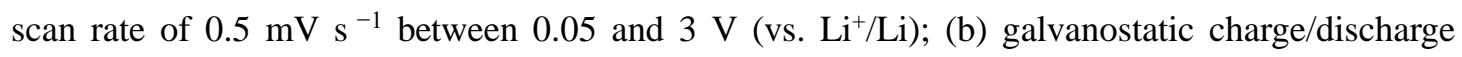
voltage profiles for the first three cycles between 0.05 and $3 \mathrm{~V}\left(\mathrm{vs} . \mathrm{Li}^{+} / \mathrm{Li}\right)$ at a current density of $100 \mathrm{~mA} \mathrm{~g}^{-1}$; (c) cycling performance and (d) rate capability of FPys (red), FPcs (blue), and $\mathrm{Fe}_{3} \mathrm{O}_{4}$ (black) micro/nanospheres electrodes in the voltage window of $0.05-3 \mathrm{~V}\left(\mathrm{vs} . \mathrm{Li}^{+} / \mathrm{Li}\right)$. 

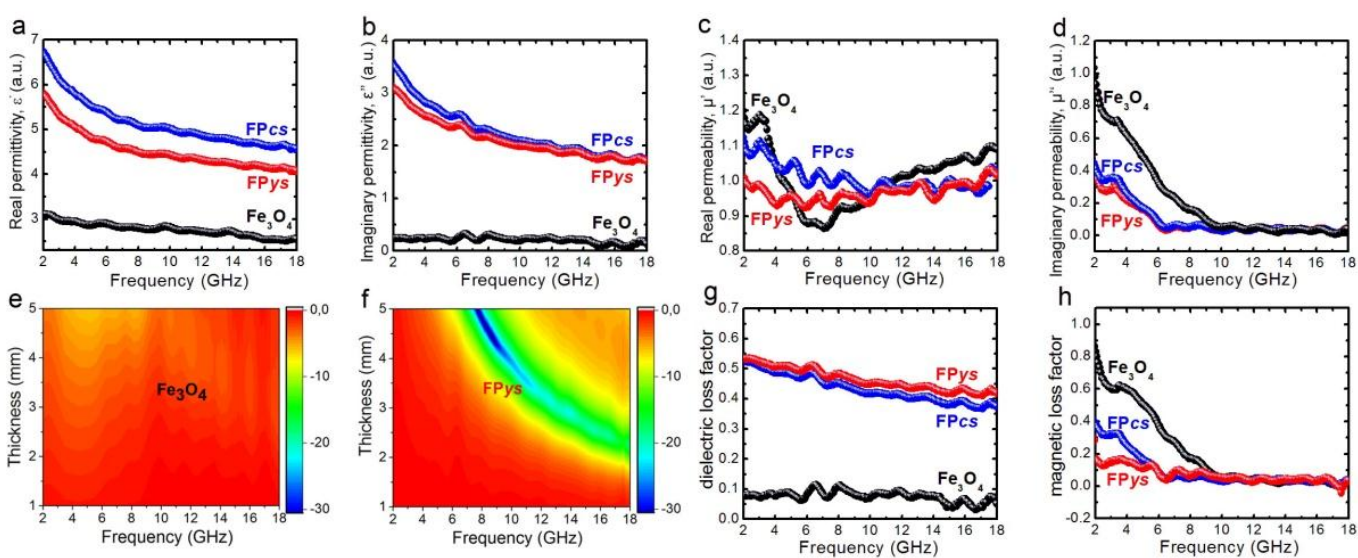

Fig. 6. Frequency dependent (a) real $\left(\varepsilon^{\prime}\right)$, (b) imaginary $\left(\varepsilon^{\prime \prime}\right)$ parts of permittivity, and (c) real $\left(\mu^{\prime}\right)$,

(d) imaginary $\left(\mu^{\prime \prime}\right)$ parts of complex permeability of FPys, FPcs, and $\mathrm{Fe}_{3} \mathrm{O}_{4}$ micro/nanospheres;

reflection loss maps of (e) $\mathrm{Fe}_{3} \mathrm{O}_{4}$ micro/nanosphers and (f) FPys in the frequency range of 2.0-18.0 GHz with varied absorber thickness from 1.0 to $5.0 \mathrm{~mm}$; (g) dielectric loss factor and (h) magnetic loss factor of FPys, FPcs, and $\mathrm{Fe}_{3} \mathrm{O}_{4}$ micro/nanospheres. 


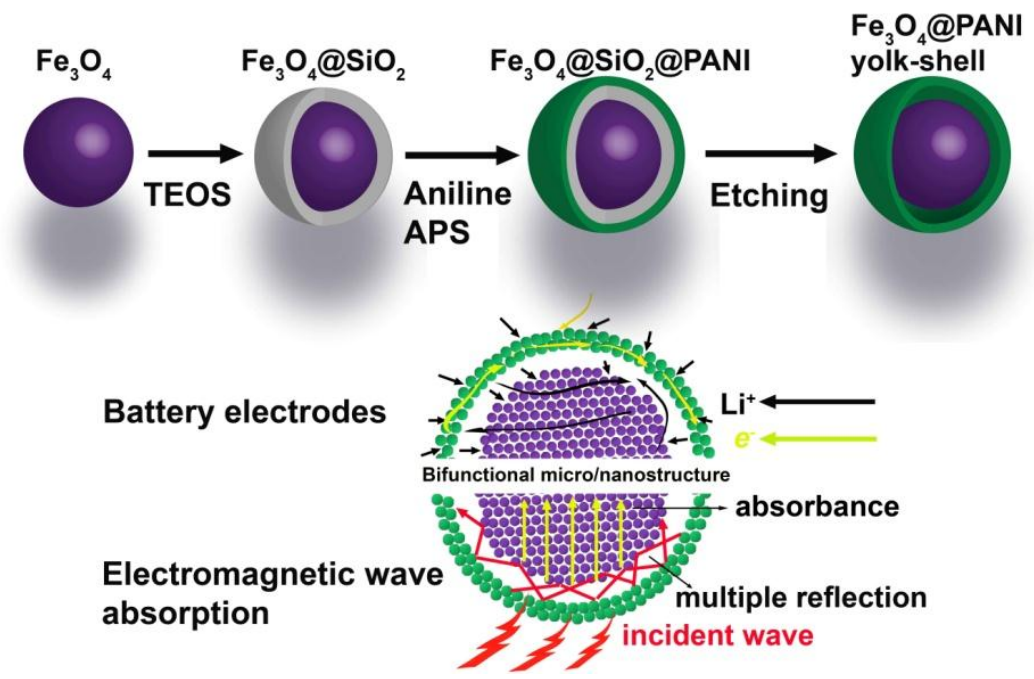

Scheme 1. Schematic illustration of the formation process of FPys micro/nanospheres; the bifunctional principle of the FPys micro/nanospheres. 
Table 1. Performance comparison of some LIB anode materials based on typical $\mathrm{Fe}_{3} \mathrm{O}_{4}$ structures

$\left(1 \mathrm{C}=1000 \mathrm{~mA} \mathrm{~g}^{-1}\right)$.

\begin{tabular}{|c|c|c|c|c|}
\hline material & $\begin{array}{l}\text { reversible capacity(cycles) } \\
/ \mathrm{mA} \mathrm{h} \mathrm{g}^{-1}\end{array}$ & $\begin{array}{l}\text { rate capability } \\
/ \mathrm{mA} \mathrm{h} \mathrm{g}^{-1}\end{array}$ & $\begin{array}{l}\text { voltage window } \\
\left.\text { /V (vs. } \mathrm{Li}^{+} / \mathrm{Li}\right)\end{array}$ & Ref \\
\hline Hollow ball-in-ball $\mathrm{Co}_{\mathrm{x}} \mathrm{Fe}_{3-\mathrm{x}} \mathrm{O}_{4}$ & $650.2(100) @ 1 \mathrm{C}$ & $201.6 @ 10 \mathrm{C}$ & $0.005-3.0$ & 18 \\
\hline $\mathrm{Fe}_{3} \mathrm{O}_{4}$ microflowers & $1000(50) @ 0.1 \mathrm{C}$ & $840 @ 1 \mathrm{C}$ & $0.05-3.0$ & 19 \\
\hline $\mathrm{Fe}_{3} \mathrm{O}_{4} / \mathrm{Fe}$ nanocomposites & $390(50) @ 0.2 \mathrm{C}$ & $260 @ 2 \mathrm{C}$ & $0.05-3.0$ & 20 \\
\hline $\mathrm{TiO}_{2}$ and $\mathrm{Fe}_{3} \mathrm{O}_{4}$ with graphene & $703(200) @ 0.5 \mathrm{C}$ & $169 @ 8 \mathrm{C}$ & $0.01-3.0$ & 21 \\
\hline Graphene oxide/ $/ \mathrm{Fe}_{3} \mathrm{O}_{4}$ composite & $350(60) @ 0.5 \mathrm{C}$ & $200 @ 3 \mathrm{C}$ & $0.005-3.0$ & 22 \\
\hline $\mathrm{Fe}_{3} \mathrm{O}_{4} / \mathrm{CNTs} / \mathrm{rGO}$ composite & $1048(50) @ 0.2 \mathrm{C}$ & $540 @ 10 \mathrm{C}$ & $0.01-3.0$ & 23 \\
\hline $\mathrm{Fe}_{3} \mathrm{O}_{4} @ \mathrm{~N}$-doped carbon nanoparticles & $860(500) @ 1 \mathrm{C}$ & $180 @ 7 \mathrm{C}$ & $0.01-3.0$ & 24 \\
\hline $\mathrm{Fe}_{3} \mathrm{O}_{4}$ nanocrystals/garphene nanosheets & $983(180) @ 0.1 \mathrm{C}$ & $323 @ 5 \mathrm{C}$ & $0.01-3.0$ & 25 \\
\hline Graphene-doped carbon/ $\mathrm{Fe}_{3} \mathrm{O}_{4}$ nanofibers & $872(100) @ 0.1 \mathrm{C}$ & $455 @ 5 \mathrm{C}$ & $0.01-3.0$ & 26 \\
\hline $\mathrm{Fe}_{3} \mathrm{O}_{4}$ nanorods/N-doped graphene & $929(50) @ 0.1 \mathrm{C}$ & $491 @ 4 \mathrm{C}$ & $0.01-3.0$ & 27 \\
\hline Grapheme and carbon-coated hollow $\mathrm{Fe}_{3} \mathrm{O}_{4}$ & $870(100) @ 0.1 \mathrm{C}$ & $285 @ 10 \mathrm{C}$ & $0.005-3.0$ & 28 \\
\hline $\mathrm{Fe}_{3} \mathrm{O}_{4} @$ polypyrrole nanocages & $950 @ 0.2 \mathrm{C}$ & $490 @ 5$ C & $0.01-3.0$ & 29 \\
\hline Carbon-encapsulated $\mathrm{Fe}_{3} \mathrm{O}_{4}$ nanoparticles & $806(100) @ 0.1 \mathrm{C}$ & $573 @ 1.5 \mathrm{C}$ & $0.005-2.5$ & 30 \\
\hline $\mathrm{Fe}_{3} \mathrm{O}_{4} @ \mathrm{MOF}$ core-shell microspheres & $1002(100) @ 0.1 \mathrm{C}$ & $429 @ 2 \mathrm{C}$ & $0.01-3.0$ & 31 \\
\hline Carbon-covered $\mathrm{Fe}_{3} \mathrm{O}_{4}$ hollow cubic & $1126(100) @ 0.1 \mathrm{C}$ & $492 @ 0.5 \mathrm{C}$ & $0.01-3.0$ & 32 \\
\hline Yolk-shelled $\mathrm{Fe}_{3} \mathrm{O}_{4} @$ carbon & $1012(70) @ 0.1 \mathrm{C}$ & $900 @ 5 \mathrm{C}$ & $0.01-3.0$ & 33 \\
\hline Carbon-coated $\mathrm{Fe}_{3} \mathrm{O}_{4}$ & $1001(50) @ 0.1 \mathrm{C}$ & $317 @ 2 \mathrm{C}$ & $0.01-3.0$ & 34 \\
\hline Nanofibrous $\mathrm{Fe}_{3} \mathrm{O}_{4}-\mathrm{TiO}_{2}$-carbon composite & $525(100) @ 0.1 \mathrm{C}$ & $70 @ 5$ C & $0.01-3.0$ & 35 \\
\hline $\mathrm{Fe}_{3} \mathrm{O}_{4}$ micro/nanospheres & $305(50) @ 0.1 \mathrm{C}$ & $286.2 @ 1 \mathrm{C}$ & $0.05-3.0$ & this work \\
\hline $\mathrm{FP} c s$ & $632(50) @ 0.1 \mathrm{C}$ & $660.2 @ 1 C$ & $0.05-3.0$ & this work \\
\hline FPys & $982(50) @ 0.1 \mathrm{C}$ & $734.6 @ 1 C$ & $0.05-3.0$ & this work \\
\hline
\end{tabular}

